\title{
The Relationship of Dietary Pattern with Health Status of Elderly in the Area of Teladan Health Center in Medan
}

\author{
Henny Oktaviani Siregar ${ }^{1}$, Erna Mutiara ${ }^{2}$, Linda T Maas ${ }^{3}$ \\ Faculty of Public Health, University of Sumatera Utara \\ Medan, Indonesia \\ oktaviani_henny@ymail.com \\ erna3@usu.ac.id \\ linda@kissfm-medan.com
}

\begin{abstract}
Globally, the elderly population is predicted to increase continously. The elderly population in Indonesia is predicted to increase higher than the population in the world. The increase is accompanied by dietary changes that affect the health status of the elderly. This research was conducted at Teladan health center in Medan, based on data from Teladan Health Center in Medan obtained data of non communicable disease in elderly who visited Teladan health center in 2016, the highest is hypertension, heart disease and diabetes mellitus. The purpose of this research was to determine the relationship between dietary pattern with health status of the elderly in the work area of Teladan Health Center in Medan. This study used cross sectional design, with sampling using total population from all elderly targeted by Teladan Health Center in Medan. Independent variable is dietary obtained through interview using food frequency and food recall questionnaires, and the dependent variable in this research is health status of elderly. The analysis is univariate and bivariate with Chi-square. The results showed that health status in elderly in Teladan Health Center still low. Result : The result of bivariate analysis shows that there is a significant correlation between dietary pattern with health status of the elderly. Conclusion: Based on the results of the above research it is advisable to keep the diet well and regularly as well as increasing the knowledge related to diet so that the health status of the elderly becomes high.
\end{abstract}

Keywords - Globally; Dietary; Health Status; Elderly; Population

\section{INTRODUCTION}

Elderly is a natural process that can not be avoided Aging or getting old is a situation that happens in human life. The process of aging is a lifelong process, not only starting from a certain time, but starting from the beginning of life [1].

Increased growth of the elderly population began to be felt since 2000 which is the number of elderly 14.4 million people with increase of $7.18 \%$ with life expectancy 64.5 years old, in 2010 the elderly population is estimated as much as 23.9 millions people with improvement of $9.7 \%$ with life expectancy of 67.4 years old. In 2014, the number of elderly in Indonesia reaches 20.24 million people, equivalent to 8.03 percent of the total population of Indonesia. Indonesia is included in the top five countries with the world's largest number of elderly people, estimated by 2025 , the number will reach 36 million people [2].

In 2008, 2009 and 2012 the percentage of the elderly population has reached above $7 \%$ of the total population. The aging population structure is one of the indicators of success in achieving human development globally and nationally. According to World Health Organization, 70\% of deaths are caused by heart disease, stroke, cancer, and diabetes. Half of that amount is associated with bad diet. Dietary changes occur almost all over the world, both in developed and developing countries [3]. People are beginning to shift from the traditional diet to an unbalanced diet that is low in fiber and high in fat so it can cause various diseases [4].

Based on the Central Bureau of Statistics (2015), the morbidity of the elderly population in 2014 is $25.05 \%$, it means that out of every 100 elderly people there are 25 of them experiencing illness [5]. Results of Riskesdas 2013, showed that most non-communicable diseases in elderly that is hypertension, arthritis, stroke, chronic obstructive pulmonary disease (COPD) and diabetes mellitus (DM) [6].

In general, the health status of the elderly population is still low, this can be seen with the increase of percentage of elderly population who have health complaints from 2005 that is $48.94 \%$ until 2012 that is equal to $52.12 \%$. Disease in the elderly is often different from young adults, because the disease in the elderly is a combination of disorders that arise due to disease and aging process, which is the slow disappearance of the body tissue's ability to repair themselves or replace themselves and maintain normal structure and function, resist disease (including infection) and repair damage suffered.

The percentage of risk food eating behaviors has increased from 2007 to 2013. In the diet of fatty foods the percentage increased sharply from $11 \%$ (in 2007) to $37.7 \%$ (in 2013), the proportion of the consumption of foods or soft drinks was $53.1 \%$, and salty food eating behavior increased slightly from $23.1 \%$ (2007) to $24.8 \%$ (2013).

A good pattern of food consumption positively affects people as well as maintaining health and preventing or helping 
to cure illness. In society, the pattern of food consumption is also called eating habits. Eating patterns in the elderly in the regulation of the amount of food as an energy source should contain all the nutrients, such as carbohydrates, proteins, fats, minerals, vitamins, and water in sufficient quantities according to the needs of the elderly and must be balanced in composition [7]. Survey at Teladan Health center, obtained data of PTM in elderly who visited Teladan health center in 2016 , the highest is hypertension that is equal to $40.9 \%$, heart disease $35.7 \%$, and diabetes mellitus disease is $38.5 \%$ [8].

Physical health manifests when a person does not feel pain and is clinically absent. All organs of the body function normally or there is no disruption of body function. While mental health can be seen from 3 components: mind, emotional and spiritual [9]. Emotional mental disorder is the same term as psychological distress. This condition is a condition that indicates a person is undergoing a psychological change. Unlike psychosis and schizophrenia, mental emotional disorder is a disorder that can be experienced by all people in certain circumstances, but can recover as before. This disorder may continue to be a more serious if not successfully overcome. Emotional mental disorders are not expected to develop more seriously if people who experience it can cope or perform treatment as early as possible to a health care center or seek medical attention to a competent health.

Health status is good when there is physical examination no disease, normal blood pressure, negative emotional mental status (no disturbance) in accordance with the data obtained from the health center. On the other hand, the status of elderly health is not good if the health condition of elderly in whole both physically and mentally during physical health examination there is disease, abnormal blood pressure (high / low blood pressure), positive emotional mental status, disturbance [2].

Become elderly, physiological function has decreased due to degenerative process (aging) so that non-communicable diseases appear in elderly. In addition, degenerative problems reduce the immune system so susceptible to infectious diseases. Non-communicable diseases in the elderly include hypertension, stroke, diabetes mellitus and arthritis or rheumatism. While infectious diseases suffered are tuberculosis, diarrhea, pneumonia and hepatitis. The elderly morbidity rates are the proportion of elderly people who have health problems to interfere with daily activities. Mortality rate is one of the indicators used to measure the health status of the population. Morbidity is classified as a negative health indicator. The lower the morbidity rate, indicating the health status of the better population [10].

Lifestyle changes such as eating foods high in calories and lack of physical activity is one of the triggers for the emergence of degenerative diseases such as diabetes mellitus, high blood pressure (hypertension), heart disease and stroke. Dietary patterns in the elderly should be eating foods with balanced nutrition that is not high in calories and accompanied by high physical activity but not excessive, but in reality through preliminary survey are still many elderly who consume foods high in calories and lack of physical activity. Therefore, based on the background, it is necessary to conduct research on dietary with health status of elderly at Teladan Health Center in Medan.

\section{METHOD}

This research used observational analytic study with cross sectional design, with sampling technique using total population from all elderly targeted by Teladan Health Center in Medan that is 102 samples. Independent variables were dietary obtained through interview using food frequency questionnaire and food recall questionnaire 24 hours. Measurement of diet in the elderly in this study using Food Frequency Questionnaire method, which is a method to calculate the frequency of food intake consumed at certain intervals and Food recall 24 hours to calculate the intake of the amount of food intake consumed. The questionnaire used in the food frequency questionnaire method consists of two basic components, the food list and the frequency of consumption to assess how often a food is consumed.

The advantage of this method is the questionnaire analysis which is quite simple and cheap because the list of food types contained in the questionnaire has been modified in accordance with the pattern of public consumption [11]. Dependent variable in this research is health status of elderly. Data analysis method used was univariate and bivariate with Chi-square test with $95 \%$ confidence interval (CI). Univariate analysis aims to explain or describe the characteristics of each research variable. In general, univariate analysis only produces frequency and average distributions depending on the type of data. In bivariate analysis used is statistical chi-square test is an analysis to determine the relationship between independent variables with dependent variable, using $\alpha=0.05$ (95\% confidence degree).

\section{RESULT}

Data were analyzed univariate and bivariate

1. Univariate Analysis

TABLE 1.

DISTRIBUTION OF FREQUENCY BASED ON DIETARY AND HEALTH STATUS OF ELDERLY IN WORKING AREA OF TELADAN HEALTH CENTER IN MEDAN

\begin{tabular}{|l|c|c|}
\hline \multicolumn{1}{|c|}{ Variabel } & Frequency & \% \\
\hline Dietary & 76 & 74,5 \\
Bad & 26 & 25,5 \\
Good & & \\
\hline Health Status & 60 & 58,8 \\
Bad & 42 & 41,2 \\
Good & & \\
\hline
\end{tabular}

In the table shows that based on the most diet is the elderly who has a bad diet that is as many as 76 people $(74.5 \%)$ and based on health status, most are elderly with health status is bad as many as 60 people $(58.8 \%)$. 
TABLE II

FREQUENCY DISTRIBUTION OF RESPONDENTS BASED ON CARBOHYDRATE INTAKE IN THE WORKING AREA OF TELADAN HEALTH CENTER IN MEDAN

\begin{tabular}{|c|c|c|}
\hline Carbohydrate Intake & Frequency & $\%$ \\
\hline Excessive & 42 & 41.2 \\
\hline Sufficient & 56 & 54.9 \\
\hline Less & 4 & 3.9 \\
\hline Total & 102 & 100.0 \\
\hline
\end{tabular}

In the table shows that the proportion of elderly based on the most carbohydrate intake is elderly with enough carbohydrate intake, that is 56 people $(54.9 \%)$, excessive carbohydrate intake; 42 people $(41.2 \%)$ and less as many as 4 people $(3.9 \%)$.

Foods that contain carbohydrates can divided into 2 groups, namely food with simple carbohydrate content (eg : sugar, candy, soft drinks, and several types of bakery products) and food with complex carbohydrate content (eg : grains, tubers, cereals, and nuts) [12]. The results of this study indicate that carbohydrate consumption in elderly is sufficient. in the elderly, a person will experience a decrease in the sense of taste and smell that can cause decreased appetite. In addition, many elderly who began to lose teeth causing discomfort when chewing.

Elderly decreased physiological function in the oral cavity so affect the process of food mechanism. Changes in the cavity mouth that occurs in the elderly includes the date of teeth, dry mouth, and decreased esophageal motility. Decreased system function digestion in the elderly is the physiological function of the oral cavity affect the process of food mechanism. In the elderly, a lot of teeth that date and gum damage due to degeneration process. Both of these things greatly affect the process of chewing food. Elderly have difficulty consuming hard food consistency. The salivary glands are difficult to secrete that affect the process complex carbohydrate changes to disaccharides due to ptialine enzymes decreased [13].

TABLE III

FREQUENCY DISTRIBUTION OF RESPONDENTS BASED ON PROTEIN INTAKE IN THE WORKING AREA OF TELADAN HEALTH CENTER IN MEDAN

\begin{tabular}{|c|c|c|}
\hline Protein Intake & Frequency & $\%$ \\
\hline Excessive & 43 & 42.2 \\
\hline Sufficient & 49 & 48.0 \\
\hline Less & 10 & 9.8 \\
\hline Total & 102 & 100.0 \\
\hline
\end{tabular}

Table shows that the proportion of elderly based on the highest protein intake is elderly with sufficient protein intake, 49 people $(48.0 \%)$, excessive protein intake, 43 people (42.2\%), and less as many as 10 people $(9.8 \%)$.

The energy that the body needs is obtained from carbohydrates, proteins and fats. Protein is needed by the body as a building agent and cell maintenance. Protein maintenance is good for very elderly important because protein synthesis in the body of its function already decline in elderly and many cell damage [13]. Some studies have found that older people require a greater proein intake to maintain balance of nitrogen. However, the relationship decreases intake proteins can have a major effect on cell function decline, so there is often a decrease in muscle mass, decreased endurance against illness. While the protein needs will increase when an elderly person is in a clinical state such as severe infection, fever or surgery.

Indonesian people generally using carbohydrates as the biggest energy contributor because serve as staple food. Excessive energy intake will affect the occurrence of degenerative diseases due to excess energy will be stored in the form of fatty tissue. This can resulting in more weight [14]. In the elderly there is a decrease in various cell functions along with age. The result is the cell's ability to digest protein is much more decreased than non-elderly, so overall will decrease the need for protein intake which will happen to all elderly. This is caused by decline in body functions that occur naturally and can not avoided.

TABLE IV

FREQUENCY DISTRIBUTION OF RESPONDENTS BASED ON FAT INTAKE IN THE WORKING AREA OF TELADAN HEALTH CENTER IN MEDAN

\begin{tabular}{|c|c|c|}
\hline Fat Intake & Frequency & $\%$ \\
\hline Excessive & 15 & 14.7 \\
\hline Sufficient & 39 & 38.2 \\
\hline Less & 48 & 47.1 \\
\hline Total & 102 & 100.0 \\
\hline
\end{tabular}

Table shows that the proportion of elderly based on the highest fat intake is elderly with less fat intake, 48 people $(47.1 \%)$, adequate protein intake, 39 people $(38.2 \%)$, and excessive as many as 15 people (14.7\%).

Consumption of fat in the elderly should be reduced because decreased physical activity so that any energy needs. The recommended fat consumption is $30 \%$ or less total calories needed. High total fat consumption (more than $40 \%$ of energy consumption) can cause atherosclerosis (blockage of blood vessels toward the heart). Elderly protein requirement per day in healthy condition is $\pm 0.8 \mathrm{~g} / \mathrm{kg}$ body weight or 15 $25 \%$ of energy requirement [13].

\section{Bivariate Analysis}

TABLE V

DISTRIBUTION OF RELATIONSHIP BETWEEN DIETARY AND ELDERLY HEALTH STATUS IN THE WORKING AREA OF TELADAN HEALTH CENTER IN MEDAN

\begin{tabular}{|c|c|c|c|c|c|c|c|c|}
\hline \multirow[t]{3}{*}{ Dietary } & \multicolumn{4}{|c|}{ Health status } & \multirow{2}{*}{\multicolumn{2}{|c|}{ Total }} & \multirow{3}{*}{$\begin{array}{c}P \\
\text { value }\end{array}$} & \multirow{3}{*}{$\begin{array}{c}R P(C I=95 \\
\%)\end{array}$} \\
\hline & \multicolumn{2}{|c|}{ Bad } & \multicolumn{2}{|c|}{ Good } & & & & \\
\hline & $\mathbf{N}$ & $\%$ & $\mathbf{N}$ & $\%$ & $\mathbf{n}$ & $\%$ & & \\
\hline $\mathrm{Bad}$ & 53 & 69.7 & 23 & 30.3 & 76 & 100 & 0.01 & 2.590 \\
\hline Good & 7 & 26.9 & 19 & 73.1 & 26 & 100 & & $\begin{array}{c}(1.352- \\
4.963)\end{array}$ \\
\hline
\end{tabular}

The result of bivariate analysis between dietary with elderly health status was obtained from 26 elderly people with good diet, 7 elderly $(26,9 \%)$ had bad health status and 19 
people $(73,1 \%)$ good health status, while from 76 elderly people whose diet is not good with bad health status there are 53 people $(69,7 \%)$ and 23 people $(30,3 \%)$ good health status. Pursuant to result of statistical analysis of Chi Square test obtained value $\mathrm{p}=0,01$ ( $\mathrm{p}<0,05)$ meaning there is significant relation between diet with elderly health status. From the results of this analysis also obtained Ratio prevalence value of $2.42(95 \% \mathrm{CI}=1.60-3.65)$, it is mean that the elderly who has a good diet has a 2.42 times risk to have a good health status compared with the elderly with a bad diet.

\section{DISCUSSION}

In bivariate analysis the relationship between diet with elderly health status with Chi Square test statistic obtained $\mathrm{p}$ value $=0.01(\mathrm{p}<0.05)$ which means there is a meaningful relationship between diet with elderly health status. This is in line with study about the relationships of lifestyle with elderly health status in the work area of Pasar Merah Health Center in Medan. The results showed that there was a relationship ( $\mathrm{p}=$ $0.001)$ between diet and elderly health status [15].

Appropriate diet can affect health, productivity and the spirit of the elderly. However, given the physical and biological conditions that have decreased, making the elderly should adjust his diet specifically. Decrease in this condition for example, elderly often complain of difficulty eating meat and hard food due to dental and gum disorders. In addition, they also often feel uncomfortable when consuming milk, because intolerant lactose plus loss of appetite due to decreased sense of taste. The balanced menu for the elderly is the composition of foods that contain enough all the nutrients needed by the elderly. Guidelines for food for the elderly is to eat foods that contain a diverse and adequate nutrition, easy to digest and chew food, quality protein sources such as milk, eggs, meat and fish. Should consume complex carbohydrates, dietary sources of fat should come from fats, consuming food sources of iron as spinach, nuts and green vegetables [7].

Dishes served for the elderly at meals should contain a variety of nutritional needs for the elderly. Type of food served should be easily chewed and digested by the elderly body, because along with the age of the elderly, digestive system has decreased function. The intended type of dish should contain the right variety of nutritional elements for the elderly, such as eating complex carbohydrate sources, containing vegetable fats, vitamins and protein. The elderly is not recommended to consume preserved foods or fast food. Preserved and fast food has a bad content for the health of the elderly.

Eating healthy and nutritious foods for the elderly can be arranged with the pattern of eating healthy food daily with the right amount. The type and amount of food consumed by the elderly should contain about $55-60 \%$ of calories, protein about $0.8 \mathrm{~g} / \mathrm{kg}$ body weight / day, less than $30 \%$ caloric fat, vitamins (A, B12, C) and enough minerals.

The better of the elderly's diet will increase health status. Diet should be noted because the bad dietary pattern will cause some diseases. In this case the diet in the elderly mostly including not good (bad). According to the results of interviews with the elderly who eat well they say that in Teladan health center, they often get information about good diet such as food should not be too salty or too sweet, eat must be regular pattern and balanced,while the elderly who have a bad diet so lazy to apply it in their life. The unbalanced dietary intake of good intake of both amount and type of food, such as eating foods high in fat, consuming less vegetables, fruits and so on also eat foods that exceed the needs of the body can cause obesity [2].

Eating fast food has now become very popular for the children to adults. Currently there is a change in the pattern of food consumption in the elderly with a tendency to choose foods that have a high composition of calories, high fat and low fiber. Type of fast food is also favored by the elderly because it is considered more practical, comfortable and does not spend a long time so it can be presented anytime and anywhere [16]. Diet is a variety of information that gives an idea of the variety and amount of food eaten every day by one person and is a sign for a particular group of people. Unbalanced diet is bad for the health of all age groups, lack of physical activity can lead to disrupted metabolism, if it lasts long it will cause various diseases.

The elderly group is seen as a community group at risk of health problems such as increased physical functional disability and often have problems in terms of eating. Though although the activity decreases with age, elderly still require intake of complete nutrition, like carbohydrate, protein, fat. Elderly still require energy to perform the physiological functions of his body [17].

The research about lifestyle of elderly in Kasihan Bantul districts, Yogyakarta, the result shows that elderly aged 60-70 years old who consume junk food $(71 \%)$, where food packaging is a kind of food selected by elderly as much as 50 $\%$, and foods containing saturated fat is the most consumed type of food is $86 \%$.[18].

\section{CONCLUSION}

Bivariate analysis between dietary with elderly health status was obtained from 26 elderly people with good diet, 7 elderly $(26,9 \%)$ had bad health status and 19 people $(73,1 \%)$ good health status, while from 76 elderly people whose diet is not good with bad health status there are 53 people $(69,7 \%)$ and 23 people $(30,3 \%)$ good health status. Pursuant to result of statistical analysis of Chi Square test obtained value $p=0,01$ $(\mathrm{p}<0,05)$ meaning there is significant relation between diet with elderly health status. From the results of this analysis also obtained Ratio prevalence value of 2.42 ; it is mean that the elderly who has a good diet has a 2.42 times risk to have a good health status compared with the elderly with a bad diet.

Advised on the elderly to improve and regulate food consumption to suit nutritionally balanced diet and It is advisable to Teladan Health Center in Medan to develop a program that motivates many elderly people such as doing group discussion to keep the diet well and regularly so that the health status becomes high.

\section{ACKNOWLEDGMENTS}

I am grateful to the head of the health facility for their assistance in this research. I am also thankful to all of the 
participants and people who were involved in this research. No conflict of interest.

\section{REFERENCE}

[1] Azwar, A, “ Pedoman Pembinaan Kesehatan Usia Lanjut Bagi Petugas Kesehatan, Jawa Timur, 2006.

[2] Nugroho, " Keperawatan Gerontik," Medical Book, EGC: Jakarta, Jakarta, 2008.

[3] WHO, "Health Promotion Glossary," 1998

[4] Santoso, "Membonsai Hipertensi," Surabaya: Temprina Media Grafika, 2010.

[5] Central Bureau of Statistics, "Elderly Population Statistics 2014," Jakarta: The Central Bureau of Statistics, 2015.

[6] Health Ministry of the Republic of Indonesia, "Riset Kesehatan Dasar," Jakarta, 2013.

[7] Maryam, R. S., Ekasari, M. F., Rosidawati, Jubaedi, A., Batubara, I, "Mengenal Usia Lanjut dan Perawatannya," Jakarta: Salemba Medika, 2008.

[8] Teladan Health Center, " Profil Puskesmas Teladan, Medan,” 2016.
[9] Notoatmodjo,S, “ Promosi Kesehatan, Teori dan Aplikasi. Cetakan II,' Jakarta : Rineka Cipta, 2010

[10] Health Ministry of the Republic of Indonesia, "Gambaran Kesehatan Lanjut Usia Di Indonesia, Buletin Jendela Data Dan Informasi Kesehatan," Jakarta, 2013.

[11] Pietinen, P, "Penilaian Konsumsi Pangan, Gizi Kesehatan Masyarakat," Jakarta: EGC, 2009.

[12] Pharr, J. R, "Carbohydrate Consumption And Fatigue: A Review," Nevada Journal of Public Health, 7(6): 38-45, 2010.

[13] Fatmah, "Gizi Usia Lanjut,” Jakarta : Erlangga, 2010.

[14] Proverawati, A and Wati, E K, “ Ilmu Gizi untuk Perawat dan Gizi Kesehatan," Yulia Medika, Yogyakarta, 2011.

[15] Sidabutar.S, “ The Relationship of life style with Elderly Health Status in the Working Area of Pasar Merah Health Center 2014,”. University of Sumatera Utara, 2014.

[16] Putra, R, " Junk Food Berkontribusi Terhadap Kinerja Buruk dan Obesitas," 2013

[17] Adriani, M, Wirjatmadi, B, "Peranan Gizi Dalam Siklus Kehidupan," Jakarta: Kencana Prenada Media Group, 2012. Jakarta, 2008.

[18] Ridwan dan Nurwanti, "Lifestyle and Hypertension at Elderly in Kasihan Bantul Districts Yogyakarta, Journal of Ners and Midwifery of Indonesia (JNKI), Vol.2, No.2, pp:67-70, 2014. 